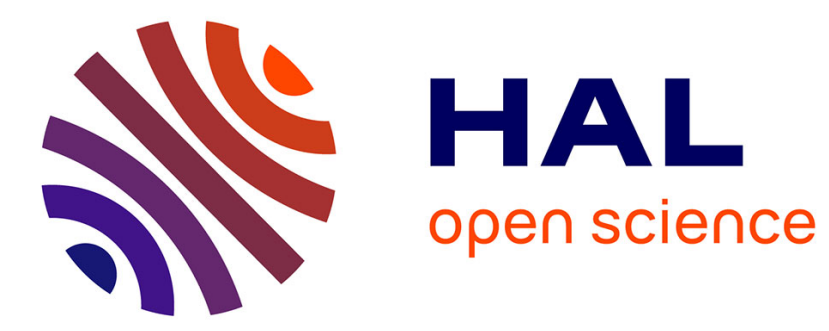

\title{
The Mouvement des Forces Démocratiques de Casamance: The Illusion of Separatism in Senegal?
}

\author{
Vincent Foucher
}

\section{To cite this version:}

Vincent Foucher. The Mouvement des Forces Démocratiques de Casamance: The Illusion of Separatism in Senegal?. Lotje de Vries; Pierre Englebert; Mareike Schomerus. Secessionism in African Politics, Palgrave Macmillan, pp.265-292, 2018, Palgrave Series in African Borderlands Studies, 9783-319-90206-7. 10.1007/978-3-319-90206-7_10. halshs-02479100

\section{HAL Id: halshs-02479100 \\ https://shs.hal.science/halshs-02479100}

Submitted on 12 Mar 2020

HAL is a multi-disciplinary open access archive for the deposit and dissemination of scientific research documents, whether they are published or not. The documents may come from teaching and research institutions in France or abroad, or from public or private research centers.
L'archive ouverte pluridisciplinaire HAL, est destinée au dépôt et à la diffusion de documents scientifiques de niveau recherche, publiés ou non, émanant des établissements d'enseignement et de recherche français ou étrangers, des laboratoires publics ou privés. 


\title{
The Mouvement des Forces Démocratiques de Casamance: The Illusion of Separatism in Senegal?
}

\author{
Vincent Foucher
}

\section{INTRODUCTION}

On December 26, 1982, the Mouvement des Forces Démocratiques de Casamance (MFDC) voiced for the first time its demand for the independence of Casamance, the southern region of Senegal. This demand launched the longest, currently running violent conflict in Africa. The MFDC can thus lay claim to having led Africa's second "secessionist moment" of the 1980s, after the first secessionist phase of the 1960s. Over the years, the Casamance conflict has killed several thousand people. It has been a discrete conflict though, with low-intensity violence and little of the extreme brutality that has made some African wars infamous. A peace process has been dragging on since 1991 and violence has waned. Over the past ten years, separatist guerrillas have been involved only in a

${ }^{1}$ Englebert and Hummel (2005: 421).

\section{Foucher $(\bowtie)$}

Les Afriques dans le Monde, Centre National de la Recherche

Scientifique - Sciences-Po Bordeaux, Pessac, France

e-mail: v.foucher@sciencespobordeaux.fr

(C) The Author(s) 2019

L. de Vries et al. (eds.), Secessionism in African Politics,

Palgrave Series in African Borderlands Studies,

https://doi.org/10.1007/978-3-319-90206-7_10 
handful of incidents. Has it all been an "illusory" separatism, as Englebert ${ }^{2}$ puts it, a bargaining chip for local elites trying to renegotiate the terms of their incorporation to the Senegalese state and appropriate local institutions? Can this hypothesis be reconciled with the duration of the conflict?

To answer these questions, this chapter by and large follows the chronology, partly because so much is, in our times, in Casamance and elsewhere, about history: history lived and told, history forgotten and remembered, history discussed and disputed. As much as a history of Casamance, the first part provides a history of the idea of Casamance, how it was formed and transformed, up to the point when it could become the basis for a popular demand for separation. The second part discusses the "rest of the story," the complex interactions between the MFDC, the state, the communities, and the sub-regional environment since 1982.

Far from being the manifestation of an eternal essence, Casamançais separatism is the late-1970s recombination of an earlier elite regionalism with a sense of ethnic Diola identity. A key factor in this buildup has been the existence and influence of a literati class among the Diola, with its difficulties and debates about nation-statehood. This explains both the strong commitment of many separatists and the subdued character of the conflict, for the Senegalese state has been able to remain open to the Diola, making clear that the separatist option was just one of the many ways for Casamance to be.

\section{A History of the Idea of Casamance}

Nationalism, as Anderson and Gellner have both shown, is embedded in a specific form of historical consciousness. ${ }^{3}$ This first part thus tries to give a sense of history of Casamance as it has been written by academics but also as it has been taken up (and re-crafted) from the late 1970s by the separatist narrative. Casamançais separatism is best understood as an essentialist recast of a tradition of elite regionalism by a larger and less dominant group, the growing number of Diola literati. In this social segment, where life choices and chances had been so much about the state, a weakening of that state stimulated reflections on history, statehood, and citizenship. Casamançais separatism is one such reflection, an attempt to imagine, with reference to the past, what a "proper" nation-state could look like.

\footnotetext{
${ }^{2}$ Englebert (2009: 156).

${ }^{3}$ Anderson (1991 [1983]) and Gellner (1983).
} 


\section{A History of Difference and Resistance?}

As many current African political entities, neither Casamance nor Senegal had any pre-colonial existence: their borders were drawn in the nineteenth century through struggles and deals involving European powers and a host of African entities, from aristocratic states with slave armies to federations of villages. Before the arrival of the Europeans in the late fifteenth century, the area comprised between the Senegal River valley and currentday Guinea was the western march of the Mali Empire. Mali was a polycentric area over which Malinke rituals, trade networks, and language acted as fragile cement. The societies of the Atlantic Coast strove to escape tributary dependency. New nodes of power formed in the territories that now make North Senegal, while much of current-day Casamance was connected to another node, that of Kaabu, centered on the northeast of current-day Guinea-Bissau. ${ }^{4}$ While Malinke and Fula ethnic identities have dominated Middle and Upper Casamance, respectively, an indication of a connection to the networks of Sahelian West Africa and the Malinke world, the swamps and forests of Lower Casamance lent themselves well to groups that kept a greater distance from Kaabunke influences. From the nineteenth century, these groups, which, unlike the Fula and Malinke, were entirely absent from North Senegal, were by and large subsumed by French ethnography under the exo-ethnonym of Diola, which they have since adopted. ${ }^{5}$

Until the late nineteenth century, it was the Portuguese who were most active along the Casamance river, which they named after one of the nearby kingdoms, that of the king (mansa in Malinke) of Kasa, a tributary of Kaabu. In 1645, they created the trade post of Ziguinchor. But they did not exert sovereignty over substantial tracts of land along the Casamance river in the seventeenth and eighteenth centuries. In the early nineteenth century, traders and administrators of the French colony of Senegal, then a scattering of trade posts along the coast of what is now North Senegal, started to look elsewhere. To the French coming from the

\footnotetext{
${ }^{4}$ On the Kaabu, see Barry (1988); and Lopes (1999). The author acknowledges the feedback on previous drafts of Séverine Awenengo, Mark Deets, Jean-Claude Marut, MarieEmmanuelle Pommerolle, and Jordi Tomàs, as well as the comments of the anonymous reviewers.

${ }^{5}$ Portuguese ethnography used the ethnonym "Felupos," still in use in Guinea Bissau.
} 
arid Senegalese north, Casamance and its better rainfalls and forests seemed to offer exciting opportunities, especially Lower Casamance and its productive indigenous rice cultivation and rubber trees. Thus was born the theme of Casamance as a wealthy area, a potential breadbasket for the rest of Senegal. France negotiated treaties of "alliance" and "protection" and built trade posts in Carabane and Sédhiou. They cut a deal with Portugal in 1886, taking over Ziguinchor but did not incorporate the British Gambia. As a result, while part of the colony of Senegal, Casamance was separated from it by The Gambia. Certainly, then as now, to those that look at a map and those that experience the crossing of The Gambia on the way to North Senegal, this outstanding geographical oddity has played a part in making separation thinkable. ${ }^{6}$

By the end of the nineteenth century, France set out to administer the Casamance river valley. This was not easy, particularly with the Diola of Lower Casamance, among whom social hierarchy then was limited and there were no strong, obvious elites to co-opt. Initial attempts to designate North Senegalese (nordiste) or Malinke colonial auxiliaries as administrative chiefs were not conclusive. The locals that were subsequently recruited struggled to establish credibility beyond their own village, oscillating between passivity and ruthlessness. ${ }^{7}$ In the colony of Senegal, it was only among the Diola that French pressure on resources and manpower led to revolts during World War I. ${ }^{8}$ During World War II, a handful of Diola villages revolted again, and the French suspected a young Diola prophetess, Aline Sitoé Diatta, who had established an influential rain cult. She was deported to, and died in, Timbuktu. What seems to have been a mistake on the part of the French lived on: in the 1970s, Aline Sitoé emerged as a symbol of resistance by both Senegalese leftist nationalists and Casamançais separatists. ${ }^{9}$

To the French officials, the Diola were "animist" and "primitive," a forest people without state and writing - not high on their Senegambian

${ }^{6}$ Defenders of a Casamançais difference note that Casamançais used to say "I am going to Senegal" when travelling from Casamance to Dakar (and some still do today), their adversaries point out that people from the Senegal river valley or Eastern Senegal say the same and have not asked for independence.

${ }^{7}$ Méguelle (2013).

${ }^{8}$ Roche (1985 [1976]).

${ }^{9}$ See Toliver-Diallo (2005); and Baum (2016). 
civilizational ladder. Most of the Muslim and Christian auxiliaries of the French, often nordiste ethnic Wolof familiar with the European mores, were no less prejudiced. So Casamance was special in the mind of the French administration: its high development potential of course but also its strange geography, its remoteness, and Diola "culture" (though that culture was only one of several present in Casamance). On a number of occasions, French officials and traders called on the authorities to grant some autonomy, or even separation from Senegal. ${ }^{10}$ But French policy never went beyond specific administrative structures at one moment or another: military administration, yes, or an administrateur supérieur devoted to Casamance, between the commandants de cercle and the governor of Senegal.

The Catholic Church too was thinking hard about Casamance, with more positive connotations. In the nineteenth century, operating from a North Senegal that was Islamizing fast, it began looking to the promising "animist" Diola of Lower Casamance. While critical of Diola "paganism," missionaries construed the image of moral and harmonious rural communities prone to convert to Catholicism. In 1939, Casamance was turned into an apostolic prefecture, separate from the vicariate of Dakar, and placed under the direction of one of the very first African bishops. This was an indication of the region's position in the imagination of the Church. That apostolic prefecture extended much further east than the administration's Casamance and included what are now the regions of Tambacounda and Kédougou, and their tiny animist groups, which were also "interesting" to the Church.

It is precisely this extended Casamance, "from the Atlantic to the Falémé river," that the leading separatist ideologue of the 1980s, a Diola Catholic priest, Father Augustin Diamacoune Senghor, came to adopt in his elaboration of Casamançais nationalism. ${ }^{11}$ As many thinkers of Casamance, Church officials tended to talk of Casamance as a whole while often actually meaning the Diola-populated Lower Casamance. ${ }^{12}$ The

${ }^{10}$ Lambert (1998; 589-591); Awenengo Dalberto (2005).

${ }^{11}$ Marut (2010: 58).

${ }^{12}$ Indeed, nowadays, it is the Kasa, the southwestern portion of Lower Casamance where Islam is the least strong and where traditional Diola religious institutions are at their strongest, which is seen as the real Casamance, a process which Marut (2005: 315) has aptly called a double reduction. 
Church was eventually frustrated in its hopes, for in the late nineteenth and early twentieth century, many Diola brought back Islam from their time as migrant laborers on the groundnut fields of the Muslim Malinke in the British Gambia. ${ }^{13}$ Today, the Catholics are a minority in Casamance, even among the Diola. The resentment of the Casamançais Catholic circles vis-à-vis the eventual triumph of Islam, which they perceived as backed by the colonial and postcolonial state, fed the construction of a Casamançais difference by the MFDC, though this must not be taken to mean that the separatist conflict is over religion. ${ }^{14}$

Another influence in early debates over Casamance was the "Portuguese" Mestizo elite of Ziguinchor. Initially unhappy with the French takeover, they were keen to gain autonomy for their city (rather than for Casamance) from the North Senegalese urban centers. Along with resident metropolitan French and a few Africans blessed with formal education or colonial favor, they enjoyed full citizenship, as opposed to the bulk of African sujets, who were subjected to a derogatory judicial code and to forced labor. Ziguinchor's citoyens petitioned and obtained from the administration a degree of autonomy for their municipality as early as $1907 . .^{15}$

The history of Casamance is thus one of late incorporation in the colony of Senegal. Unlike North Senegal, where contacts had been going on for centuries, Casamance had few points of connection to the French in the early colonial era. The Diola area stood out on this count, for in Middle and Upper Casamance, there were Fula and Malinke Muslim leaders with whom France eventually worked out deals. With the Diola, unmediated first encounters were often difficult.

Colonial perceptions of Casamançais difference, those of administrators, missionaries, and nordiste auxiliaries, formalized by locally influential French scholars such as historian Christian Roche and anthropologist

\footnotetext{
${ }^{13}$ Mark (1978).

${ }^{14}$ Contrary to what hasty analysts have argued, neither Casamance nor Lower Casamance host a majority of Catholic (and/or followers of a traditional African religion): just like in North Senegal, Muslims have long been a majority in Casamance, even among the Diola. No matter Father Diamacoune's leadership, the MFDC is a religious mix, just like Casamance itself, and has never declared itself against Islam. What is true is that Lower Casamance hosts one of the most significant Catholic (and "animist") minorities in Senegal. Foucher (2003).

${ }^{15}$ Trincaz (1984: 43).
} 
Louis-Vincent Thomas, ${ }^{16}$ have fed separatist intellectuals. Occasionally subverting the stigma, they have produced an essentialist narrative of difference, insisting the pre-colonial history and cultures of Casamance and North Senegal had little in common-a judgment that is as disputable as the reverse position. ${ }^{17}$ They too have given a central part to the Diola, highlighting their egalitarian, acephalous culture, claiming that unlike most nordiste groups, they had no hierarchies (which is open to debate), had always refused to take part in the slave trade (which is wrong), and had always resisted conquest (which is too general). ${ }^{18}$ The image of the self-reliant, moral, and fiercely independent Diola peasant has been the founding vignette of Casamançais nationalism. It has made a structural pair with a damning stereotype of the nordistes as disrespectful and lazy liars and profiteers, only too ready to collaborate with invaders.

As an echo of the inspiration it found in classificatory colonial ethnography, Casamançais nationalism claims to take root in nature itself. It draws a strong contrast between the pristine environment of Casamance as supposedly preserved by the Diola, the strong rainfalls, lush forests, and prosperous rice fields of its Guinean climate, and the desolate Sahel taken to typify North Senegal-supposedly the victim of its greedy inhabitants. ${ }^{19}$ Separatist discourse has also been looking for, and unsurprisingly, finding,

\footnotetext{
${ }^{16}$ See Thomas (1958-1959) and C. Roche (1985 [1976]). Thomas' structuro-functionalism lends itself well to essentialism. Roche was the head of the Ziguinchor lycée in the early 1970s and his 1976 book on the conquest and resistance of Casamance has been a major source for the MFDC, providing some of its favorite quotes, such as Governor General Van Vollenhoven's complaint in 1917: "We are not the masters of Lower Casamance. We are only tolerated there."

${ }^{17}$ For a sample of MFDC discourse, see the commented separatist text in Darbon (1985).

${ }^{18}$ On slavery in pre-colonial Diola society, see Linares (1987) and Baum (1999). According to Baum, the acephalousness of Diola society noted from the nineteenth century could be the product of the fracturing of more hierarchical structures. The current existence of sets of villages falling under the ritual purview of certain "priests-kings" could be a vestige of these structures.

${ }^{19}$ The expression "Casamance naturelle" has been in wide use in the Senegalese parlance, especially since the division of the administrative region of Casamance in two and then three units (Ziguinchor and Kolda in 1984, and then Sédhiou in 2008). It testifies to the persistence, even in pro-Senegalese thought, of the sense of a Casamançais difference steeped in the natural environment.
} 
validation in colonial history itself, claiming (wrongly) that France had administered Casamance separately from the colony of Senegal. ${ }^{20}$

The idea of a radical discontinuity between Lower Casamance and North Senegal has been central in the scholarly debate on Casamançais separatism. Darbon (1988) has thus identified the Diola's acephalous political culture as a cause for lasting connection problems. Diop and Diouf as well as Gasser have insisted that given the centrality of the "Islamo-Wolof model" in Senegal, the powerful combination of maraboutic Islam and business networks typical of the Wolof core that have dominated North Senegal and mediated with the state from the colonial times, the Diola are structurally on the losing end of statehood. ${ }^{21}$ More recently, Boone has argued that the early colonial pattern of "administrative occupation," an authoritarian, unmediated, and unresponsive state, has endured in Lower Casamance, and is the reason for separatism. ${ }^{22}$ There is no doubt that the experience of the state in Lower Casamance has been specific. But it would be a mistake to focus exclusively on the early days of the French presence: in the late colonial era, an educated Diola elite developed, operating in the Senegalese framework while developing a regionalist sensibility.

\section{After 1945: Triumph of the Évolués And Birth of an Enduring Regionalist SEnsibility}

World War II was a political turning point as it saw the emancipation of the sujets in colonial Senegal. Until then, politics had been dominated by the minority African citoyens from the Quatre Communes, the four old sites of French presence in North Senegal-Dakar, Gorée, Saint-Louis, and Rufisque. The moderate Socialist Section Française de l'Internationale Ouvrière (SFIO) had been hegemonic. After 1945, provinces throughout Senegal took to defending their share against the Quatre Communes.

\footnotetext{
${ }^{20}$ In the framework of the OAU charter, the MFDC's claim makes sense: if indeed colonial borders are the basis for postcolonial states, it is important to be able to argue that Casamance and Senegal were separate in the colonial era. But Englebert and Hummel (2005: 419-420) are probably right in assuming that the colonial "evidence" is mobilized primarily to the benefit of an internal audience.

${ }^{21}$ Diop and Diouf (1990) and Gasser (2000).

${ }^{22}$ Boone (2003).
} 
Among the Diola, a particularly large and influential new class of literati led this process.

Indeed, after the war, the young Diola became particularly interested in formal education. This seems to have to do with the intense "modernist anxiety" typical of those latecomers in colonial society analyzed in the neighboring Guinea by $\mathrm{McGovern}^{23}$ : the communities that are construed as particularly primitive by the colonial power and that occupy the bottom of the colonial hierarchy of ethnic groups, such as the Loma in Guinea and the Diola in Senegal. These communities are "the Other's Other"-the other of the "civilized" indigenes of the Quatre Communes or the Muslim nordistes, in this instance, themselves already the other of the French. They can become particularly keen to catch up. ${ }^{24}$

In Lower Casamance, with the Catholic Church and the late colonial state at the ready to help, formal education offered relatively accessible opportunities. As early as 1955 , about $10 \%$ of school classes in Senegal were found in Lower Casamance, which amounted to only about $5 \%$ of the population. Thirty years later, the region of Ziguinchor would have a $100 \%$ gross primary education rate, while the national average would be less than $60 \% .{ }^{25}$ This signifies an educational revolution, and it is perhaps here-rather than in the supposedly acephalous Diola political culturewhere the real, or most politically relevant, difference of Lower Casamance lies.

In the booming 1950s cities of North Senegal, the arrival of the aspiring évolués from the "pagan" forests was not always easy. On their part, there was desire and resentment. And on the part of many nordistes, there were (and indeed still are) more or less negative stereotypes - the Diola as bizarre, rough, and somewhat threatening pagan primitives far removed from the Franco-Islamo-Wolof urbanity elaborated in the Quatre Communes. ${ }^{26}$ There were cases of discrimination, humiliation, and contempt. But the 1950s were overall times of expansion, equalization, and

${ }^{23}$ McGovern (2013).

${ }^{24}$ It is remarkable that the one Diola community that had taken the lead in conversion to Islam and groundnut cultivation, the Buluf subgroup, also led the way in education and, later, in support for separatism.

${ }^{25}$ Foucher (2011: 88).

${ }^{26}$ Tomàs (2010: 155) gives a modern-day example of the persisting nordiste sense of centrality: a nordiste soldier reproaches an old Diola with having a bizarre Diola name, instead of a « classic » (to him), Muslim one.... 
Africanization of the colonial service, and many of the first Diola évolués made decent careers as state functionaries. They converted many Diola to what Anderson has called the secular "pilgrimages" of the state, the circulation in a new uniform nationalized space for formal education and state employment. ${ }^{27}$

The évolués became major influences in the villages, bringing new cultural practices (ballroom dancing, football, and theater) and taking care of développement: they raised funds and labor and lobbied the authorities to build new classes, taught summer schools, organized health centers, and kindergarten. They also tried to fight ritual female genital mutilation and the migration of young Diola women to Dakar. ${ }^{28}$ Diola women had been engaged in urban employment for some time, usually as maids for the nascent bourgeoisie. Migration allowed them to escape the patriarchal order, assert autonomy, marry "out" or never quite, which was a situation deemed abject by the dignified évolués. But the latter's reservations had little impact, for the women were able to embed migration in the village communities. Still, the concern about female migration has remained a feature of Diola évolué thought, and grew more acute when the new Diola masculinity was called into question by the crisis of the Senegalese state pilgrimages. $^{29}$

After 1945, the aspiring évolués throughout Senegal found their man: Léopold Sédar Senghor, a young ethnic Serer nordiste intellectual born a sujet. ${ }^{30}$ In October 1948, he left the SFIO to create the Bloc Démocratique Sénégalais (BDS). He allied with the elites of former sujets, including a leading Diola évolué, Emile Badiane, who created in 1949 the MFDC, from which the current separatist movement draws its name. ${ }^{31}$ The first MFDC fought not for separation but for proper political representation of Casamance in the new Senegalese public sphere, which meant that

${ }^{27}$ Anderson (1991).

${ }^{28}$ On female Diola migration, see among others Lambert (1999).

${ }^{29}$ Lambert (1999) and Foucher (2005).

${ }^{30}$ The homonymy with Father Diamacoune Senghor is a coincidence.

${ }^{31}$ Separatist history insists that the MFDC was created in March 1947, a date repeated since by most scholars. Séverine Awenengo, the most seasoned specialist of the late colonial Casamance, convincingly defends 1949. Perhaps the separatists were keen to establish that the first MFDC had been created before Senghor's BDS, and to allow for the inclusion in its history of a little-known figure, Victor Diatta, a Diola évolué mysteriously murdered in Dakar in 1948 and whom they see as an early martyr of their cause. 
Casamançais should hold political office for Casamance instead of people identified to Quatre Communes. ${ }^{32}$ In fact, it was SFIO adversaries of the MFDC that were the first Africans to voice the idea of separation of Casamance, in a desperate attempt to make up for their growing irrelevance in the region. ${ }^{33}$

In 1950, the MFDC formalized its alliance with the BDS. At the 1951 and 1952 elections, the BDS crushed the SFIO in Casamance as well as in the rest of Senegal except in, predictably, Quatre Communes. But Senghor's cooperation with the French authorities, his choice to get some Metropolitan French or nordiste allies elected on the "safe" Casamance lists, and his pressuring to merge the MFDC into the BDS progressively frustrated the younger left-leaning Casamance évolués. ${ }^{34}$ In June 1955, those within the MFDC who insisted it should remain autonomous from BDS created a Mouvement Autonome de Casamance (MAC). The MAC picked Assane Seck as its leader, a young Casamançais academic with nordiste origins. MAC and SFIO joined forces for the 1956 elections, making some inroads in the city of Ziguinchor but losing badly in the region as a whole.

In 1958, when all French African territories were called to a referendum on immediate independence or participation in a community of states around France, the colonial administration and some Casamançais politicians discussed a separation of Casamance from Senegal should the Senegalese majority go for independence. ${ }^{35}$ This eventuality remained unexplored, for Senegal voted a massive "yes" to the French community. ${ }^{36}$

${ }^{32}$ The distinction seems to have been a question of degree, for some Casamançais of known nordiste origin, like Ibou Diallo (born in Sédhiou in a family hailing from SaintLouis), were MFDC figures, while others fought it.

${ }^{33}$ Amadou Lamine Daffé, a citoyen and SFIO leader from Sédhiou, suggested the separation of Casamance to the Senegalese Territorial Assembly in 1948. The idea was rejected and Daffé disappeared from politics. Daffé, a former policeman and a trader, has the profile to be the missing link between French and African reflections on a separation of Casamance. See Awenengo (2005) and Manga (2012).

${ }^{34}$ In 1954, under pressure from the young radicals, MFDC went for "affiliation" to BDS instead of the "integration" proposed by Badiane. But it stopped de facto to function as a separate entity.

${ }^{35}$ Awenengo (2005).

${ }^{36}$ Separatists have alleged that the "No" vote won a majority in Casamance, a claim taken up by hasty researchers. The "No" won only $2.2 \%$ of the votes in Senegal as a whole, and $7.4 \%$ in Casamance. It was concentrated in the city of Ziguinchor and its surroundings, but it did make some progress beyond. 
While the episode does not necessarily testify to a strong Casamançais sense of difference from Senegal, it does show that a line existed that French officials could use. One has to note, however, that the French also broached the idea of separation with the autochthonous leaders of the Dakar peninsula. This secret plan was abandoned with little difficulty; the Casamançais figures involved did not mention it any further. ${ }^{37}$

It was from the anti-French side that the notion of a separation of Casamance was remobilized in the 1960s and early 1970s. In Casamance, as elsewhere in Senegal, the younger évolués were impatient with Senghor. Some supported Assane Seck, who now stood for the Parti de la Renaissance Africaine-Sénégal (PRA-S). Left-wing critics of Senghor looked to Sékou Touré, who had led neighboring French Guinea to independence in 1958 and supported the left-wing guerrilla of Partido Africano para a Independência da Guiné e Cabo Verde (PAIGC) in Portuguese Guinea, a tiny territory set between his own Guinea and Senegal. Touré's ambition, enmity toward Senghor, enthusiasm for African unity and leftist politics combined in talks of a fusion between the two Guineas and Casamance in a "Grande Guinée." In the 1960s and 1970s, there were a variety of discussions in elite leftist circles over a fusion of Casamance with The Gambia and/or the Guineas. ${ }^{38}$

The regionalist sensitivity remained, kept alive by former PRA-S figures, some of whom had rallied in 1966 Senghor's party (then called Union Progressiste Sénégalaise, UPS) that had absorbed all other legal parties. As early as 1970, a set of Casamançais literati around Mamadou Salim Cissé, a teacher at the Ziguinchor lycée, embarked on the creation of a new party, Sunu Gaal ("our canoe" in Wolof). Combining leftism with a sense of the interests of Casamance, they denounced the north-south "distomia." 39 They called not for separation but for equitable development between the

\footnotetext{
${ }^{37}$ Awenengo (forthcoming). It is probably confused memories of this episode that have come up in Father Diamacoune's hitherto undocumented claims that Badiane signed in 1960, a contract with Léopold Sédar Senghor to stay with Senegal, a contract he claims came to term in 1980. See introduction to Father Diamacoune in the following paragraphs.

${ }^{38}$ Awenengo (forthcoming).

${ }^{39}$ Centre des Archives Diplomatiques de Nantes, Fonds Dakar Ambassade 655, lettre manuscrite, Ziguinchor, le 2 novembre 1970, du Consul à Ziguinchor, Parandel, à Monsieur le Conseiller.
} 
different regions. ${ }^{40}$ Senghor was suspicious of Sunu Gaal's Casamançais roots and refused recognition. In 1974, the Sunu Gaal activists met with a nordiste lawyer, Abdoulaye Wade, also from the suppressed left. Together, they founded the Parti Démocratique Sénégalais (PDS), which became the first legal alternative party in Senegal since 1966.

A historically informed perspective thus shows that the Diola have not remained unconnected to the state. In fact, from World War II, they have engaged it more intensely than many communities in Senegal. This has been a key factor behind the particular strength of regionalism in Casamance since the late 1940s. The évolués, dependent on the state for education and employment, had expectations, a sense of common destiny, networks, and the "equipment" for politicization. Many were concerned with the imposition of non-Casamançais politicians in Casamance. Many were looking at Senegal primarily through its capital Dakar-often knowing the city from personal experience-and felt that Casamance was lagging behind. While they deployed a touchy sense of entitlement, they did not then seem interested in separation. In fact, it was the French who had first formulated the possibility of separation, an idea that then looked like a tactical move and did not quite capture imaginations in Casamance.

\section{The Late 1970s: From Regionalism to Separatism}

It was only in the late 1970s that Casamançais regionalism, under the influence of a wide array of forces, transformed into a separatist nationalism. The transformation happened under the guidance of a Diola core; the growing difficulties encountered by Diola évolués in their pilgrimages toward the state were a key element in this.

The 1970s were a time of trouble for Senegal. The ambitious developmental state dependent on dwindling groundnut exports could not cope with demographic growth and the mounting demande sociale. The exploration of alternative avenues for growth (through oil or improved rice cultivation) in Casamance produced little more than higher expectations and disappointment. There was a sense that pressure on local resources was growing along with frustration with the fact that nordiste migrants were coming to Casamance who were better equipped to profit through better access to capital and expertise in the retail trade, tourism, or fishing industries.

${ }^{40}$ Interview, founding member of Sunu Gaal, Dakar 2012-2013. 
Some Casamançais denounced the "plunder" of Casamançais forests and rivers by nordistes. While Ziguinchor and portions of the coast were undergoing expropriations in the name of development, local officials, many of them nordistes, made things worse by giving kin and clients access to land. There were protests in Ziguinchor and around the seaside resort of Cap Skirring. A student strike at the Ziguinchor lycée in 1979-1980 witnessed civilians challenging police forces as well as the powerful public intervention of the Usana, pan-Diola female associations affiliated to precolonial Diola religion.

All this resonated with issues of political representation. The death of Badiane in 1972 and the resignation in 1980 of Senghor, ${ }^{41}$ who was still viewed positively in rural Lower Casamance, did not help. The democratization initiated in 1974 had an impact too-Casamance is one of the early examples where democratization had an affinity with rising debates over autochthony. ${ }^{42}$ There were intense factional struggles within the ruling UPS (which became Parti Socialiste, PS in 1976). The old PS Mestizo elites of Ziguinchor engaged in a bitter fight within the PS over the municipality in 1977, denouncing the new PS mayor, Mamadou Abdoulaye Sy-born in Ziguinchor from a nordiste Toucouleur father and a Diola mother-as a stranger. But the Mestizo were a dwindling demographic group and a losing force. More significantly, some of Sy's adversaries within PS used the autochthony argument to try and build a base among the growing number of Diola who were settling in Ziguinchor.

The late 1970s also witnessed the development of opposition parties. The opposition PDS was influential in Casamance, thanks to Sunu Gaal, and they too denounced the local authorities in Ziguinchor as strangers. There was no shortage of grievances in Casamance, and particularly in Ziguinchor, but it was almost exclusively Diola who came out in support of separation from Senegal. This has to do with that group's social and political history. As the 1970s went by, the Senegalese state proved increasingly unable to cater to their aspirations. To reduce education spending the state cut funding for boarding schools. These had hitherto been essential for the education of young Diola with limited connections in North Senegal. And the state could not provide civil service

\footnotetext{
${ }^{41} \mathrm{He}$ resigned in December 1980 handing over power to his Prime Minister, Abdou Diouf.

${ }^{42}$ Bayart et al. (2001). Indeed, the democratization of the 1950 s had had a comparable effect.
} 
jobs for the growing number of educated Diola. For the Diola, who had collectively bet so much on education, this was terrible news.

Among the Diola migrant networks in Dakar and in France, separation began being debated seriously. In 1979, a number of Diola évolués based in France created the association Esukolal ("our place" in Diola). Among them, Mamadou Sané Nkrumah stood out: born in 1939, his quest for education had led him to France in 1967, having finished high school. A clerk at a Paris-based engineering school, he was involved in left-wing politics. From January 1981, Esukolal edited five issues of a journal, Kelumak ("the palaver tree" in Diola). It included educational material, an echo of the village summer schools. But it was primarily a celebration of Diola values, history, and heroes, and expressed a desire to rejuvenate Diola society and control female migration. It drew inspiration from the Catholic ethnography, then influenced by the theology of inculturation, which insisted the Church engage with traditional institutions and practices rather than fight them. The concomitant development of a cultural tourism that placed a high value on Diola identity played a part, too.

Esukolal reached out to Dakar and Casamance. In April 1982, on a visit to Casamance, Sané met with a number of PS and PDS politicians opposed to the local authorities, including Sanoune Bodian, a young Diola schoolteacher and PS supporter active in the land protests. He also met Father Diamacoune Senghor. Born in Casamance in 1928 and ordained in 1956, Diamacoune was a leading figure in the Catholic celebration of the Diola and their values, and ran a program on the local radio. He was also involved in local struggles, particularly in the defense of students.

Esukolal was gaining ground. In June 1982, it created a section in Dakar, and Mamadou Diémé, a cousin of Sané and technician at an academic institution, took over as the manager of Kelumak. More meetings were held in Ziguinchor, under the cover of the supporters of Casa Sport, the local football team. In the words of a participant:

The Casa [Sport], it was just a cover. There, they woke the people up, they woke the history of Casamance up. Even in [post-colonial] schools, the history of Casamance would not be taught. But [in the colonial era] there were songs dedicated to Casamance that were sung at school, but these songs were forbidden [by the post-colonial state]. The Senegalese were coming here, to do just whatever they pleased, with the mayor here, a nordiste. That was what they talked about in the meetings. ${ }^{43}$

${ }^{43}$ Interview, MFDC militant, Ziguinchor (2000). 
Plans were made to demonstrate in Ziguinchor. Despite the preventive arrest of most leaders, several hundred protesters assembled in a suburb of Ziguinchor on December 26, 1982. Unarmed, they reached the city center and flew a white flag at the governor's office. Leaflets calling for independence and the return of Aline Sitoé circulated. Only a few people were wounded. But on December 6, 1983, three gendarmes were killed during an intervention in an MFDC meeting near Ziguinchor. On December 18, 1983, militants marched again in Ziguinchor, this time with hunting rifles and machetes. It turned into a street battle, with possibly more than a hundred persons killed.

From the late 1970s, the idea of Casamance was dramatically recast: in lieu of the old évolué elites who had done well and had allied with Senghor, a younger generation of literati stood up, large in numbers and embittered. They recombined Casamançais elite regionalism with a culturalist discourse centered on the celebration of Diola identity and tradition. They owed too much to the earlier regionalist sensibility to drop Casamance as a reference altogether and focus on a purely Diola framing of the issue. ${ }^{44}$ They were critical of the old évolué generation, the "Casamanqués" (a Diamacoune pun on the French "Casamançais manqués," failed Casamançais), accused of being sellouts. This discourse found powerful echoes in what were troubled times for the population of Ziguinchor and for the Diola évolués. In the quest for development and a responsive state, the defense of the representation of Casamance no longer sufficed. A separation from Senegal, founded on a sense of radical difference and a celebration of Diola identity, offered an alternative to those who felt they had none left.

\section{Separatism, the State, and the Communities SINCE 1983}

It remains to be seen what has happened to the idea of Casamance after its violent entry on stage and how it has held up as the fundamental idea underpinning such a prolonged, but often discrete, struggle. This section gives a brief narrative of war and peace in the region and will then

\footnotetext{
${ }^{44}$ Lambert (1998: 587) hypothesizes that the MFDC insists that it is a Casamançais, not a Diola movement because of "an underlying distinction in African political ideology between nationalism and ethnicity," the former "modern" and good and the latter "backward" and bad. One could add that the MFDC cares for modernity precisely because it is a movement of the évolués.
} 
discuss the dynamics within the MFDC and the attitude of the Senegalese state. The balance of forces, the lack of international support for the MFDC and the risks and costs of offensives for both sides all explain something of the peculiar turn of this conflict. But that turn owes a lot to the persisting ambivalence of Diola society itself vis-à-vis the separatist project and to the Senegalese state's capacity to play on this ambivalence.

\section{A Brief History of War and Peace}

In the face of repression, some militants took refuge in the forests between Ziguinchor and the Guinea-Bissau border. Armed with only bows and rifles, they remained on the defensive for years. Only in April 1990 did the MFDC's armed wing, Atika ("warrior" in Diola) launch its first assault, killing two customs officers by the Gambian border. More attacks on security forces and civil servants followed, as well as armed robberies against shops and passenger vehicles. Security forces came down hard, as Amnesty International noted in a series of reports. ${ }^{45}$

But the authorities also reached out, and on March 29, 1991, a ceasefire was signed. Negotiations in Guinea-Bissau failed, leading to a rift within the MFDC. Its senior military leader, Sidy Badji, and the guerrillas operating along the Gambian border (the recently created "Front Nord") honored the ceasefire, while "Front Sud" under Léopold Sagna resumed operations along the Guinea-Bissau border. Thousands of civilians took refuge beyond the borders or in the suburbs of Ziguinchor. Front Nord would stay out of the conflict for almost a decade, keeping its zone of control and weapons and receiving assistance for "development" from Dakar.

In April 1993, Diamacoune called for a ceasefire and asked for France's arbitration regarding the colonial boundaries of Casamance, leading the way to yet another shaky agreement on July 8, 1993. Because of his controversial contacts with state officials, Léopold Sagna was deposed by younger radical fighters, among whom emerged Salif Sadio as a leader. On December 21, a France-designated expert released a report that went against Diamacoune's claims that colonial Casamance had been administered separately from Senegal. ${ }^{46}$ From 1995 to 1998, the southern front was rocked by violence, with significant losses for the Senegalese army.

\footnotetext{
${ }^{45}$ Amnesty International, La torture au Sénégal: Le cas de la Casamance, 23 May 1990.

${ }^{46}$ Charpy's report is accessible in Charpy (1994).
} 
Front Sud fought Front Nord along the Gambian border. Calls for ceasefire and state initiatives for dialogue, reliant on MFDC moderates, failed. Front Sud witnessed growing tensions between Sadio's hardliners and others closer to Diamacoune.

When a conflict broke out in Guinea-Bissau between President Nino Vieira and his armed forces chief of staff General Ansumana Mané in June 1998, Senegal rushed to the defense of Vieira while Front Sud sent fighters to support Mané ${ }^{47}$ Mané prevailed in March 1999, and Front Sud intensified operations along both the Gambian and Bissau-Guinean borders. Mediation efforts opened the way for talks in The Gambia from June 1999 (the "Banjul process"), but the more radical Sané and Sadio were not involved and violence did not abate.

The election of Abdoulaye Wade as president of Senegal in March 2000, in one of the first democratic handovers of power in postcolonial Africa, was a game changer. Wade, who had committed to solving the conflict in 100 days, made drastic choices. He called into question past arrangements with Front Nord, forbid outside mediation efforts and tried to open direct routes to Front Sud. He cultivated Guinea-Bissau's new president, Kumba Yalá, who had tense relationships with Sadio's patron in Bissau, General Mané. With the killing of Mané in a conflict with Yalá in November 2000, Senegal secured a strong alliance in Bissau. The Bissau-Guinean army, with material support from Senegal, backed MFDC moderates against Sadio. In 2001, they captured his base in Kassolol. Many MFDC fighters died in this conflict, including Sagna himself, replaced by César Badiate. In 2006, Badiate and Bissau-Guinean troops launched a final assault on Sadio, who was forced to take refuge by the Gambian border.

The threat of the Bissau-Guinean army and Senegal's financial support tied Badiate to honoring a de facto ceasefire, but the Gambian border area went up in flames. An attempt by Gambian President Yahya Jammeh to reorganize the MFDC around Front Nord moderates in June 2001 only exposed their infighting. This was a step in a spectacular escalation between Wade and Jammeh, with Jammeh accusing Wade and Front Nord of involvement in a March 2006 failed coup attempt in The Gambia. Front Nord was torn apart: some rallied to Sadio and others to Badiate.

\footnotetext{
${ }^{47}$ Mané's coup was related to Casamance, for Mané rebelled because President Nino Vieira, who had become a close partner of Senegal, was under pressure to curb the arms trade to the MFDC, and blamed it on him.
} 
Those were violent times in Northern Casamance. Wade had quickly dropped his policy of refusing mediation. A host of actors, NGOs, and politicians embarked on unequally serious mediation attempts and Senegalese money was finding its way to certain MFDC factions to broker local ceasefires. The moderates signed a peace agreement in December 2004 , and more meetings followed. The death of Diamacoune in January 2007 left the MFDC even more rudderless. Sadio remained along the Gambian border with Jammeh's sympathy. As for Front Sud, it saw a new radical faction emerge in 2009, under Ousmane Gnantang Diatta. MFDC factionalism, which did lead to instances of localized, low-intensity violence, has continued ever since.

In the March 2012 presidential elections in which Macky Sall defeated Wade, Casamance was a major issue. Sall tried to mend bridges with Jammeh and committed himself to "real" negotiations, accepting an Italian Catholic organization, Sant'Egidio, as a facilitator. ${ }^{48}$ For the first time ever, Sadio's faction entered into preliminary discussions, though real negotiations seem still a distant possibility. The downfall of Jammeh after the elections in The Gambia in 2016 and his replacement by new authorities very close to Senegal-all events in which Senegalese authorities played no small part-leaves Sadio in a more precarious situation than ever. There are now Senegalese troops on Gambian soil, and the long-awaited bridge on the Gambia river, a powerful symbol of the connection between Dakar and the Casamance, is finally being built. It remains to be seen whether this mounting pressure can push the MFDC to reunite. There have been a number of attacks - essentially on civilians - in 2018 by the other factions of the MFDC, which have supply issues and are vexed at Macky Sall's decision to focus negotiations on Sadio, but it is doubtful they can escalate. ${ }^{49}$

\section{WeAKNess and Resilience of THE MFDC Guerrillas}

Having fought - for three decades - a state that never collapsed and an army of relatively good standing, the MFDC has proven to be both weak and resilient. Protected by landmines and earthworks and drawing on the experience of veterans from the French and Senegalese army such as Badji and Sagna, the MFDC's guerrillas have kept control of forested areas

\footnotetext{
${ }^{48}$ Another nongovernmental organization, the Center for Humanitarian Dialogue, tried all the while to reach out to the other factions with Dakar's blessing, but failed.

${ }^{49}$ Badiate has a good relationship with the Front Nord moderates and has been mending bridges with Gnantang's faction, now led by Kompas Diatta. During the first semester of 2013, the Front Nord witnessed the creation of another faction led by Paul Ouloukassine Diatta.
} 
between the tarmac roads crossing Lower Casamance and the borders with The Gambia and Guinea-Bissau. They have also been adept at hit-and-run operations elsewhere. Yet despite a number of attempts, they were never able to take control of the region's cities of Ziguinchor, Oussouye, and Bignona. This mix of weakness and resilience can largely be explained by the organizational history of the movement itself (Foucher 2007b).

The first thing of note is that the turn to arms was not planned but improvised by militants on the run. The movement fed on the desire of many to take revenge and protect themselves from state repression, which seemed to validate the MFDC's discourse about the ill treatment of Casamance. Separatists embarked on campaigns to spread the word and grow rural roots-tapes and tracts circulated and meetings were organized. ${ }^{50}$ This discourse had concrete accents: the MFDC was offering prospects, talking of the positions and advantages that early supporters might obtain after independence. Some parents encouraged their children to join for that reason. Many took the 1991 ceasefire as a sign that the MFDC was indeed going somewhere.

The absence of planning meant that Atika started out with neither significant armament nor a resource base. While the 1990 offensive had to make do with a one-shot delivery of automatic weapons by Mauritania, which had had a run-in with Senegal in April 1989, international assistance to the separatists has remained scarce. Dakar has always been suspicious of its two small neighbors, The Gambia and Guinea-Bissau, both hosting Diola minorities. And it is true that the border areas have been essential for the guerrillas, which depend on refugees in both countries. ${ }^{51}$ There have been moments of tension, for instance, when Senegalese and Bissau-Guinean troops exchanged fire over a border issue in 1990, or when Jammeh, himself a Diola, accused Dakar of involvement in a coup attempt against him in 2006.

Yet Banjul and Bissau realize Senegal's strength and have had a complex, transactional approach to the Casamance conflict. ${ }^{52}$ In fact, Wade was able to clientelize the army of fragile Guinea-Bissau and have it put

\footnotetext{
${ }^{50}$ For a transcription of a rare mid-1980s recorded MFDC propaganda session, see Gasser (2000).

${ }^{51}$ See, respectively Evans and Ray (2012); and V. Foucher (2013).

${ }^{52}$ Senegal is a giant relative to its neighbors. It covers about $200,000 \mathrm{~km} 2$, Guinea-Bissau only 36,000, and the Gambia 11,300. Senegal counted 12.8 million inhabitants in 2011, Gambia 1.7 million inhabitants in 2008, and Guinea-Bissau 1.5 million in 2009.
} 
pressure on the refugees, forcing Front Sud into a quasi-ceasefire. ${ }^{53}$ Jammeh, president of the less fragile Gambia until his downfall in 2017, played a complex game of tension and appeasement with Dakar, often acting as a facilitator and knowing not to go too far.

With little foreign assistance, the MFDC had to improvise an economic base. Through the 1980s, activists practiced fundraising/requisition/banditry in the communities and fundraising in the diaspora. As time went by, stable frontlines were drawn. Front Sud, in collaboration with the refugees in Guinea-Bissau, exploited the abandoned lands, producing cannabis, palm oil and palm wine, game, and cashew nuts. Banditry against village shops and passenger vehicles was frequent. By the Gambian border, sustained violence came only after 2000, and the exodus of civilians was limited. Guerrillas there were established among communities, living off the taxation of the lively border trade with The Gambia, a country famous for its cheap consumer goods and demand for agricultural products such as milk, palm oil, charcoal, timber, and cannabis. ${ }^{54}$

Banditry became significant there, too, in the 2000s. For the guerrillas, life has been better nearer the Gambian border, possibly helping to make separatism an option for young Diola men with no better prospects. Fighters tend to marry much younger than other males, to take but one indication of their relative prosperity. This has allowed Atika to renew its troops somewhat, bringing in younger, more rural, less-educated men. But overall this has made for a war economy with low profits, limiting the MFDC's capacity to maintain and equip a large body of troops. Some guerrillas move between the bush and civilian life according to the situation on the ground. Estimates of the number of combatants are thus wild guesses, but at present, the various groups together probably count a few hundred active fighters in all.

This decentralized economy and the incapacity of the external wing and the internal political wing to durably finance the guerrillas have done much to fragment the MFDC. It has also fed the fighters' populist critique of the "politicals," held to be living abroad or in Ziguinchor in comfortable conditions (and sometimes indeed in Senegal's pay). It has allowed

\footnotetext{
${ }^{53}$ Instability in Guinea-Bissau has occasionally called Senegal's influence into question, and the emergence of Gnantang's more radical faction in 2009 may have had something to do with the killing of Dakar's favorite partners in Bissau.

${ }^{54}$ Indeed, some sources insist that cannabis producers in the Djibidione area did much to convince the MFDC to establish a base in their area, to keep the Senegalese security forces at bay.
} 
the different military camps to keep away from one another, nourishing divisions. Radicals used to be content to consider as sellouts all those who had agreed to formal and informal ceasefires. While those adhering to informal ceasefires have indeed often benefited from state monies, they mention the movement's lack of resources, its weak offensive capability, tough living conditions in the bush, and the absence of prospects for independence as the real reasons for their restraint.

The war has so far not affected the fundamental Diola-ness of the MFDC, though some factions have with for now limited success tried to extend activities to the region of Kolda. ${ }^{55}$ This may be because the MFDC owes so much to the history experienced and "written" by the Diola évolués. The state's criticism of the movement's ethnocentrism and its Diola-targeted repression may have contributed, too. While activists keep insisting on the MFDC's multi-ethnicity, one is still hard pressed to find its significant non-Diola figures. ${ }^{56}$ As for the war itself, it has kept to what are now the administrative regions of Ziguinchor and Sédhiou, the area of Diola settlement.

A final trait resulting from the movement's organizational specificity is that the guerrillas have been embedded in certain communities. This has been a factor of resilience, while forcing the fighters to listen to civilian voices and "behave." There have been notable episodes of violence and abuse, including several massacres, against non-Casamançais civilians in the 1990s and early 2000s, resulting in their displacement. Over the same period, civilians associated with the state-chiefs or civil servants for instance-were often targeted. At times, civilians trying to collect wood or cashew nuts on MFDC-controlled territory have been attacked, sometimes gruesomely. ${ }^{57}$ But by and large, Casamance guerrillas have abstained from the extreme abuses observed in many African conflicts: campaigns of rape or mutilation, or the use of child soldiers or sex slaves. Though "living with someone who has a weapon is never a good thing," guerrillas are

55 There are indications that some Fula youth have joined though.

${ }^{56}$ One of the few names that come to mind is that of the now defunct military leader Vieux Faye, a Diola-ized Serer born by the Guinea-Bissau border. Some MFDC electronic communications are signed with patronyms identified with non-Diola groups, but these could be pseudonyms (http://www.members.tripod/casamance).

${ }^{57}$ The most notable massacres include those perpetrated in Pointe Saint-Georges and Cap Skirring in 1992, and in Bélaye and Niahoump in 2001. Each incident saw the death of a dozen or a few dozen people. 
not a big cause for concern in many of the communities among which they are settled. ${ }^{58}$ This special link has played a part in moderating the MFDC, especially when the Senegalese state proved able to maintain and even revamp its links with the population.

\section{The Senegalese State: Still Standing}

Reactions of the Senegalese state have been a major variable in the MFDC's destiny. While there was no lack of repression, it is remarkable that dialogue was engaged and reforms made very early. As early as 1983, a new generation of Diola cadres was promoted and a review of land disputes launched. Casamance became a testing ground for decentralization. Following reports by Amnesty International, efforts were made in terms of human rights. Yet the real turning point came when Wade stuck to a cautious, less aggressive use of the military, which was rather well symbolized by his decision to designate a Diola as a minister of the Armed Forces.

More important still is that the separatists could never call into question the survival of the state, nor its existing connections to the Diola. The Diola have been a massive presence in Dakar and other nordiste cities since the 1960s, and the war and its damages to the regional economy have probably led more Diola north. While there were some investigations and arrests among the Diola diaspora, the state did not let this escalate into systematic discrimination. It made sure for instance that, while the Senegalese press maintained a loyalist stand, it did not feed the hatred against the Diola. Overall, the Diola were able to keep experiencing "Senegality," study, come to Dakar, marry outside of their community, serve in the army, and so forth. While many North Senegalese stick to the stereotype that all Diola are rebels (indeed, this is frequent joke when a nordiste meets a Diola), the debate over separation has been running within Diola society itself, with many embracing, or at least bearing with, Senegal as their country. ${ }^{59}$

\footnotetext{
${ }^{58}$ Interview, female civilian resident of a Front Nord controlled area, district of Bignona (2004) and personal communication from Rudolf (2013).

${ }^{59}$ Lambert (1998) and Foucher (2011). Tomàs (2010) notes that the MFDC had difficulties getting purchase in areas of the Diola subregion of Huluf because people there bore with Senegal but had little interest in an alternative. Interestingly, that sub-region was long one of the least affected by the "modernist anxiety."
} 
Since Wade's time, as the economy has recovered and donors have grown more supportive, the state has been able to revamp the old dreams of "development" in Casamance. There have been a lot of unfulfilled promises, but a public university was opened in Ziguinchor, as were many new schools and high schools in villages. Civil service has recruited and improved wages and conditions. An effort has been made at rural electrification. No surprise, then, that between this and the lull in the conflict, President Wade fared well in Casamance in all elections, including in the election that resulted in his defeat in 2012. The MFDC has been losing some of its relevance in a country that has been feeling a bit better, in a region whose economy has been upset by the conflict and where many have been experiencing Senegal as something relatively positive. NGOs and local associations, buoyed by the boost in aid, have been busy "developing" Casamance and creating links with the guerrillas to secure access and negotiate local ceasefires.

Efforts have not infrequently taken a cultural form, with some actors drawing on international and government support to mount symbolic counterattacks. With different degrees of sincerity, authenticity, and impact, initiatives have insisted on the ethnic variety of Casamance or have pointed to the mythical kinship between the Diola and the North Senegalese Serer. Casamançais icons have been included in the Senegalese pantheon and community institutions drawn into the peace process. ${ }^{60}$ The priest-kings, typical of certain Diola groups, have come to be recognized and courted by the state and politicians, being treated somewhat as equivalents of the marabouts of North Senegal. These efforts have called into question both the idea of a radical Casamançais difference from North Senegal and that of the unanimity of the people of Casamance behind separatism. Rather more than a cause of the lull, these efforts have been the language in which the mounting popular sentiment that the conflict should end and that Senegal was not such a bad option found expression.

The debate is present among the fighters themselves, even among the most radical groups. Militants are struggling with their faith, hope, and commitment to an independent Casamance; the sustainability and relative lack of danger of armed militancy; lack of prospects for victory; and the

\footnotetext{
${ }^{60}$ On the uses of and controversies around the Serer-Diola kinship, see de Jong (2005); and Smith (2010, chap. 10 \& 11); on the Usana and other traditional religious institutions, see Foucher (2007a).
} 
vagueness of alternatives. While most affirm their separatist belief in the company of fellow separatists, many express doubts in private. Some ask outside interlocutors for advice, or even for a way out. ${ }^{61}$

The state's revival since 2000 has boosted its structural sense of superiority. There are indeed reasons to believe that Dakar is tempted to push its advantage and count on the decay of the MFDC and waning of its popular support, instead of engaging in uncertain and uneasy negotiations. ${ }^{62}$

\section{Conclusion}

The history of Casamance is a history of late inclusion into the Senegalese ensemble; this did much to construe the Casamançais and particularly the Diola as an Other in the Senegalese space. But some integration did take place, especially after World War II. The Senegalese state and the cities of North Senegal became meaningful loci for the Diola, thanks to education, migration, and public employment. Precisely because the Senegalese state was meaningful, its faltering in the late 1970s made many Diola rethink about statehood seriously. Some came to the conclusion that a separate state was best. The force of the separatist resentment and the sincerity of the commitment of many of its supporters mirrored how powerful the dream was that the Senegalese state stimulated among the Diola. Incidentally, the case of Casamance confirms the connection that exists between nationalism and the experience (good and bad) of the secular pilgrimages organized by the state. Formal education is a process with huge moral and material consequences.

In an exercise in selective history writing, separatists built on networks of Diola literati well-equipped to receive a new nationalist project, infusing a tradition of elite regionalism with a new sense of difference nourished by Diola culturalism. This explains why some local elites have associated with the MFDC in one way or another. But the second MFDC, the separatist MFDC, was never of the elites. It is in part the result of turning education into a mass product - and with that devaluing it. The leaders of the separatist MFDC were, logically enough, clerks, schoolteachers, and a Catholic priest.

${ }^{61}$ An experience repeatedly made by the author of the present text, and humanitarian workers and journalists.

${ }^{62}$ Marut (2010: chap. 7). 
A movement from below, the MFDC has operated with a millenarian sincerity - a belief that fundamental social change will happen-that may not find an easy answer in institutional reform. Attempts by Casamançais elites to promote decentralization and autonomy as solutions have been seen as self-serving by Senegalese officials but also by MFDC. The defense of Casamançais identity has been endowed with a post-political capacity to redress wrongs, incarnate justice into the world, and create a seamless community. With the ambiguity of all things millenarian, Casamançais identity has been tasked to satisfy the material hopes of the Diola évolués and their families. Personal gain and collective hopes are not easily distinguished in these situations. The almost obsessive nationalist passion with which some militants still talk after 30 years is too strong to be discarded as illusory. This explains why the MFDC has not quite stopped while the local elites have been keen for it to do so.

The MFDC's roots also explain why it has been forced to hear the voices of the Diola communities. Since these communities, after the initial shock of violence, by and large worked out that Senegal was still providing an alley for much of their moral and material aspirations, the separatist cause has been locked in impossibility. The balance of forces is now more than ever in Senegal's favor, but there are still uncertainties: will Senegal engage at last in credible negotiations? Could the unpredictable internal politics of The Gambia and Guinea-Bissau affect the balance of forces in Casamance? Can separatism get purchase beyond its Diola core? Can the state sustain its essentially economic approach to the situation? How will all this affect the sense of Casamançais identity in the new generations with access to higher education, whether it be at the University of Ziguinchor or in the growing international Diola diaspora? A new wave of Casamançais separatism, while unlikely, cannot be ruled out altogether.

\section{REFERENCES}

Anderson, B. (1991). Imagined communities. Reflections on the origin and spread of nationalism. London: Verso.

Awenengo Dalberto, S. (2005). Les Joola, la Casamance et l'État (1890-2004). L'identisation joola au Sénégal. Doctoral dissertation, Université Paris VII.

Awenengo Dalberto, S. (forthcoming). Hidden debates about the status of Casamance in the decolonization process: Regionalism, territorialism and federalism at a crossroads in Senegal. In S. Awenengo Dalberto \& C. Lefêvre (Eds.), Tracing uncertainty: Boundaries, territoriality and decolonization in Africa. 
Barry, B. (1988). La Sénégambie du XVe au XIXe siècle. Traite négrière, islam et conquête colonial. Paris: L'Harmattan.

Baum, R. M. (1999). Shrines of the slave-trade. Diola religion and society in precolonial Senegambia. Oxford: Oxford University Press.

Baum, R. M. (2016). West Africa's women of God: Alinesitoné and the Diola prophetic tradition. Indiana University Press.

Bayart, J.-F., Geschiere, P., \& Nyamnjoh, F. (2001). Autochtonie, démocratie et citoyenneté en Afrique. Critique internationale, 10, 177-194.

Boone, C. (2003). Political topographies of the African state. Territorial authority and institutional choice. Cambridge: Cambridge University Press.

Charpy, J. (1994). Casamance et Sénégal au temps de la colonisation française. In F.-G. Barbier-Wiesser (Ed.), Comprendre la Casamance. Chronique d'une intégration contrastée (pp. 475-500). Paris: Karthala.

Darbon, D. (1985). La voix de la Casamance... une parole diola. Politique Africaine, 18, 125-138.

Darbon, D. (1988). L'administration et le paysan en Casamance. Paris: Pédone.

de Jong, F. (2005). A joking nation: Conflict resolution in Senegal. Canadian Journal of African Studies, 39(2), 389-413.

Diop, M. C., \& Diouf, M. (1990). Le Sénégal sous Abdou Diouf. Etat et société. Paris: Karthala.

Englebert, P. (2009). Africa: Unity, sovereignty and sorrow. Boulder: Lynne Rienner.

Englebert, P., \& Hummel, R. (2005). Let's stick together: Understanding Africa's secessionist deficit. African Affairs, 104(416), 399-427.

Evans, M., \& Ray, C. (2012). Uncertain ground: The Gambia and the Casamance conflict. In A. Saine, E. Cessay, \& E. Sall (Eds.), State and society in the Gambia since independence 1965-2012. Trenton: Africa World Press.

Foucher, V. (2003). Church and nation: The Catholic contribution to war and peace in Casamance. Le Fait Missionnaire, 13, 7-40.

Foucher, V. (2005). Les relations hommes-femmes et la formation de l'identité casamançaise. Cabiers d'études africaines, 178, 431-455.

Foucher, V. (2007a). Tradition africaine' et résolution des conflits. Un exemple sénégalais. Politix, 80, 59-80.

Foucher, V. (2007b). Senegal. The resilient weakness of Casamançais separatists. In K. Dunn \& M. Boas (Eds.), African guerrillas. Raging against the machine (pp. 171-197). Boulder: Lynne Rienner.

Foucher, V. (2011). On the matter (and materiality) of the nation: Interpreting Casamance's unresolved separatist struggle. Studies in Ethnicity and Nationalism, 11(1), 82-103.

Foucher, V. (2013). Wade's Senegal and its relations with Guinea-Bissau: Brother, patron or regional hegemon? Johannesburg: South African Institute of International Affairs, Occasional Paper 132. 
Gasser, G. (2000). 'Manger ou s'en aller': Le conflit ethnorégional casamançais et l'État sénégalais. PhD dissertation, Université de Montréal.

Gellner, E. (1983). Nations and nationalism. Ithaca: Cornell University Press.

Lambert, M. C. (1998). Violence and the war of words: Ethnicity v. nationalism in the Casamance. Africa, 68(4), 585-602.

Lambert, M. C. (1999). Have Jola women found a way to resist patriarchy with commodities? (Senegal, West Africa). Political and Legal Anthropology Review, 22(1), 85-93.

Linares, O. (1987). Deferring to trade in slaves: The Jola of Casamance, Senegal, in historical perspective. History in Africa, 14, 113-139.

Lopes, C. (1999). Kaabunke: Espaço, territorio e poder na Guine-Bissau, Gambia e Casamance pre-coloniais. Lisbon: Comissão Nacional para as Comemoracões dos Descobrimentos Portuguêses.

Manga, M. L. (2012). La Casamance dans l'histoire contemporaine du Sénégal. Paris: L'Harmattan.

Mark, P. (1978). Urban migration, cash cropping and calamity: The spread of Islam among the Diola of Boulouf (Senegal), 1900-1940. African Studies Review, 21(2), 1-14.

Marut. (2005). Marut's is Jean-Claude Marut, La question de Casamance (Sénégal). Une analyse géopolitique, thèse de doctorat, Paris, Université de Paris 8, 1999.

Marut, J.-C. (2010). Le conflit de Casamance. Ce que disent les armes. Paris: Karthala.

McGovern, M. (2013). Unmasking the state. Making Guinea modern. Chicago: Chicago University Press.

Méguelle, P. (2013). Chefferie coloniale et égalitarisme diola. Les difficultés de la politique indigène de la France en basse-Casamance (Sénégal), 1828-1923. Paris: L'Harmattan.

Roche, C. (1976). Histoire de la Casamance. Conquête et résistance (1850-1920). Paris: Karthala.

Smith, E. (2010). Des arts de faire société: parentés à plaisanteries et constructions identitaires en Afrique de l'Ouest (Sénégal). Doctoral dissertation, Institut d'Etudes Politiques de Paris.

Thomas, L.-V. (1958). Les Diola, essai d'analyse fonctionnelle sur une population de Basse-Casamance. Dakar: IFAN.

Toliver-Diallo, W. (2005). 'The woman who was more than a man': Making Aline Sitoe Diatta into a national heroine in Senegal. Canadian Journal of African Studies, 39(2), 338-360.

Tomàs, J. (2010). Casamance: el particularismo inquietante. In J. Tomàs (Ed.), Secesionismo en África (pp. 129-166). Barcelona: Bellaterra.

Trincaz, P.-X. (1984). Colonisation et régionalisme: Ziguinchor en Casamance. Paris: Orstom. 